\title{
Expression and Clinical Significance of Claudin-7, PDL-1, PTEN, c-Kit, c-Met, c-Myc, ALK, CK5/6, CK17, p53, EGFR, Ki67, p63 in Triple-negative Breast Cancer- A Single Centre Prospective Observational Study
}

\author{
CHLOE CONSTANTINOU ${ }^{1,2}$, SAVVAS PAPADOPOULOS $^{3}$, EIRINI KARYDA $^{2}$, \\ ATHANASIOS ALEXOPOULOS ${ }^{4}$, NIKI AGNANTI ${ }^{5}$, ANNA BATISTATOU ${ }^{5}$ and HARIS HARISIS ${ }^{5}$ \\ ${ }^{1}$ Breast Unit, Royal Free Hospital, London, U.K.; \\ ${ }^{2}$ Breast Unit, Hygeia Hospital, Athens, Greece; \\ ${ }^{3}$ Pathology Department, Hygeia Hospital, Athens, Greece; \\ ${ }^{4}$ Oncology Department, Hygeia Hospital, Athens, Greece; \\ ${ }^{5}$ Medical School, University of Ioannina, Ioannina, Greece
}

\begin{abstract}
Background/Aim: To explore the relationship between p53, p63, c-kit, Ki67, cMet, claudin7, CK5/6, CK17, $A R, P T E N, E G F R, A L K, P D L-1$ and $c-M Y C$ expression with the clinicopathological features of triple-negative breast cancer. Materials and Methods: Immunohistochemistry was performed in 84 triple-negative breast cancer samples. Results: A statistically significant relationship between tumour grade and claudin-7 $(p=0.004)$ and between protein $p 53$ and positive lymph nodes $(p=0.015)$ was found. High expression of claudin$7(O R=65.8,95 \% C I=4.35-995.19, p$-value $=0.003)$ and low expression of $c$-kit $(O R=0.14,95 \% C I=0.025-0.793, \quad p$ value $=0.026)$ and protein $p 63(\mathrm{OR}=0.1895 \% \mathrm{CI}=0.035-0.978$, p-value $=0.047)$ was associated with higher tumour grade. Higher AR expression (OR=13.44, 95\%CI=1.28-141.56, $p$ value $=0.031)$ and lower expression of CK5/6 cytokeratins was found in patients with positive lymphovascular invasion (LVI) $(O R=0.072,95 \% C I=0.007-0.732$, $p$-value $=0.026)$. Only the cell proliferation index (Ki67) has been proven to be statistically significant for disease-free survival ( $p$-value=0.0378), and overall survival ( $p$-value $=0.0186)$. Conclusion: High expression of claudin-7 and low expression of $c$-kit and protein $p 63$ are
\end{abstract}

This article is freely accessible online.

Correspondence to: Chloe Constantinou, Breast Unit, Royal Free Hospital, 104 Powys Lane, London, N13 4HR, U.K. Tel: +44 2088865525, e-mail: constantinou79@hotmail.com

Key Words: Triple-negative breast cancer, p53, p63, c-kit, Ki67, cMet, claudin 7, CK 5/6, CK17, AR, PTEN, EGFR, ALK, PDL-1 and $\mathrm{c}-\mathrm{MYC}$. associated with higher tumour grade. AR and CK5/6 expression seem to be important in LVI.

With over 1 million women affected worldwide, breast cancer (BC) is currently the commonest malignancy in females and the second leading cause of cancer related death (1). Triple negative breast cancer (TNBC) immunohistochemically characterized by the lack of expression of estrogen receptor (ER), progesterone receptor (PR) and human epidermal growth factor receptor type 2 (HER2), is responsible for a disproportionate share of mortality owing to its aggressive clinical behavior, poor prognosis and lack of targeted therapies (2).

Recent studies have classified TNBC into 4 major subtypes: basal-like (BLBCs), mesenchymal, luminal androgen receptor and immune enriched. Of the total cases of TNBC, $70-80 \%$ are Basal like Breast Cancers sharing numerous clinical and pathological features and these terms are often used interchangeably by clinicians although they are not synonymous. New therapeutic approaches have been proposed based on different factors, however they are not currently used to stratify patients for decisions about clinical therapy. In addition, there are no predictive markers that have been widely accepted and proven to be significant across all different studies.

The aim of the study was to explore the relationship between p53, p63, c-kit, Ki67, cMet, claudin 7, CK 5/6, CK17, AR, PTEN, EGFR, ALK, PDL-1 and c-MYC with tumor grade, number of positive lymph nodes, lymphovascular invasion (LVI), local recurrence, distant recurrence, disease-free survival and overall survival in TNBC. 


\section{Materials and Methods}

The study was performed in Hygeia General Hospital, Athens Greece from 2003-2011. A total of 84 TNBC cases were included from a prospectively collected database. Samples with an absent or incomplete immunohistochemistry report for the respective pathology were excluded. Tissue samples were fixed in $10 \%$ buffered formalin and embedded in paraffin wax. The tumors were classified and graded according to the suggested criteria of World Health Organisation (WHO) 2014 and Tumor Node Metastasis status/American Joint Committee on Cancer (TNM/AJCC) 2009 system. Suitable selected paraffin blocks containing representative tumor areas were identified on corresponding hematoxylin-eosin stained sections. Areas of interest were identified and marked on the source block. The source block was cored and a $1.5 \mathrm{~mm}$ core was transferred to the recipient "master block" using the Tissue Microarrayer (MTA-1, Beecher Instruments, Sun Prairie, WI, USA). Two, representative tumor cores were arrayed per specimen as cores of normal tissue from breast, endometrium, colon and spleen and used as reliability indicators (control). Immunohistochemical staining was performed for 14 antigens: p53, p63, c-kit, Ki67, cMet, claudin 7, CK 5/6, CK17, AR, PTEN, EGFR, ALK, PDL-1 and c-MYC.

Statistical analysis. Univariate analysis was performed to explore the association of biomarkers' expression with all the dependent variables of interest: tumor grade, number of positive lymph nodes, LVI, local recurrence (LR) and distant metastasis. Categorical variables were reported as counts and percentages and compared with Fisher's Exact test.

Multivariate logistic regression models were used for modelling the effect of biomarkers to the dependent variables tumor grade, lymph nodes and LVI. The backward elimination method with removal criterion $\mathrm{p}=5 \%$ has been used, resulting to models with statistically significant effects. Odds ratios (OR), 95\%CI and Likelihood ratio test values were reported for each analysis.

Cox proportional-hazards regression models, with backward elimination with $\mathrm{p}=10 \%$, are provided for the disease-free survival (DFS) and overall survival (OS). We also performed the Log-rank test to test the equality of survival functions.

All comparisons were two tailed and a $p$-value of $<0.05$ was considered statistically significant. Data analysis was performed using STATA statistical software version 12.0.

\section{Results}

A total of 84 patients were included in the analysis. All patients were females with median age 49 years (range $=25$ 79 years). Seventeen $(20.2 \%)$ were treated with mastectomy and $67(79.8 \%)$ with lumpectomy and radiotherapy. All patients received adjuvant chemotherapy and all histological types were invasive ductal carcinoma. The association of biomarkers with tumor grade is summarized in Table I. The analysis of the tumor grade was conducted using the degree of malignancy as a dependent variable. Fisher's exact test resulted in a statistically significant relationship between the degree of malignancy and binding of protein claudin 7 for the two different values of the biomarker, negative and weak low to strong high. Independent predictors of the grade of cancer were determined in a multivariate logistic regression model with stepwise backward elimination of variables with a $p$ value $=0.05$. The expression of claudin 7 appeared to be much higher in patients with higher tumor grade $(\mathrm{OR}=65.8$, 95\% CI=4.35-995.19, $p$-value=0.003). According to the logistic regression model for the degree of malignancy with 71 observations, there is also a statistically significant relationship with c-kit $(p$-value $=0.026)$, and protein p63 $(p$ value $=0.047)$. Their expression appeared to be lower in patients with higher tumor grade with values of odds ratio $\mathrm{OR}=0.14,95 \% \mathrm{CI}=0.025-0.793, p$-value $=0.026$ and $\mathrm{OR}=0.18$ $95 \% \mathrm{CI}=0.035-0.978, p$-value $=0.047$, respectively.

The association of lymph nodes status with the biomarkers under study is summarized in Table II. There is a statistically significant relationship between the protein p53 biomarker and the lymph nodes status according to Fisher's exact test and the multivariate logistic regression model with 71 observations, where we examined the stepwise backward elimination of variables with a $p$-value $=0.05$. The expression of protein p53 was higher in patients with positive lymph nodes $(\mathrm{OR}=3.84,95 \% \mathrm{CI}=1.22-12.07, p$-value $=0.021)$.

Independent predictors for LVI were determined in a multivariate logistic regression model with 69 observations and stepwise backward elimination of variables with a $p$-value $=0.05$. The expression of androgen receptor (AR) appeared to be much higher in those patients with positive LVI process $(\mathrm{OR}=13.44$, $95 \% \mathrm{CI}=1.28-141.56, p$-value $=0.031)$. Also, the expression of ck5/6 cytokeratins appeared to be lower in patients with positive LVI (OR=0.072, 95\%CI $=0.007-0.732, p$-value $=0.026)$.

Disease free survival and overall survival. DFS and OS status between groups of patients with different levels of each biomarker have been compared using log-rank test with a 5\% level of statistical significance. Only the cell proliferation index (Ki67) has been proven to be statistically significant for DFS ( $p$-value=0.0378), and for OS ( $p$-value=0.0186), which means that the survival function is differentiated for the two levels of the biomarker. The significance of this biomarker has also been confirmed by the Cox regression model for DFS with backward elimination $(\mathrm{HR}=0.39$, 95\% CI=0.153-0.994, $p$-value $=0.048)$. We run the same Cox regression model with backward elimination for OS and it concluded that biomarker Ki67 is an important predictor for the overall survival of patients $(\mathrm{HR}=0.277,95 \% \mathrm{CI}=0.087$ $0.886, p$-value $=0.03)$. Table III presents the results for the Log-rank test for equality of survival functions in 2 different groups of each biomarker. Kaplan-Meier graphs are provided for both OS (Figure 1), and DFS status (Figure 2).

\section{Discussion}

TNBC has unfavourable prognosis characterized by larger size and features of aggressive behavior. Many published studies 
Table I. Association of degree of malignancy with the biomarkers under study.

\begin{tabular}{|c|c|c|c|c|}
\hline \multirow[b]{2}{*}{ Biomarkers } & \multicolumn{2}{|c|}{ Degree of malignancy } & \multirow[b]{2}{*}{ Total } & \multirow[b]{2}{*}{$\begin{array}{c}\text { Fisher's } \\
\text { exact } \\
p \text {-Value }\end{array}$} \\
\hline & $\begin{array}{c}\text { Poorly- } \\
\text { moderately } \\
\text { differentiated }\end{array}$ & $\begin{array}{c}\text { Well } \\
\text { differentiated }\end{array}$ & & \\
\hline \multicolumn{5}{|l|}{ Claudin 7 n (\%) } \\
\hline Negative & $4(26.7 \%)$ & $1(1.6 \%)$ & 5 & 0.004 \\
\hline Weak low to strong high & $11(73.3 \%)$ & $61(98.4 \%)$ & 72 & \\
\hline Total & 15 & 62 & 77 & \\
\hline \multicolumn{5}{|l|}{ PTEN n (\%) } \\
\hline Negative & $13(76.5 \%)$ & $56(83.6 \%)$ & 69 & 0.492 \\
\hline Weak positive to positive & $4(23.5 \%)$ & $11(16.4 \%)$ & 15 & \\
\hline Total & 17 & 67 & 84 & \\
\hline \multicolumn{5}{|l|}{ c-met n $(\%)$} \\
\hline Negative & $6(35.3 \%)$ & $33(50 \%)$ & 39 & 0.414 \\
\hline Weak to strong positive & $11(64.7 \%)$ & $33(50 \%)$ & 44 & \\
\hline Total & 17 & 66 & 83 & \\
\hline \multicolumn{5}{|l|}{ CMYC n (\%) } \\
\hline \multicolumn{5}{|l|}{ Positive cells } \\
\hline \multicolumn{5}{|l|}{ Positive cells } \\
\hline Total & 16 & 67 & 83 & \\
\hline \multicolumn{5}{|l|}{ ckit n (\%) } \\
\hline Negative & $5(35.7 \%)$ & $41(62.1 \%)$ & 46 & 0.082 \\
\hline Positive & $9(64.3 \%)$ & $25(37.9 \%)$ & 34 & \\
\hline Total & 14 & 66 & 80 & \\
\hline \multicolumn{5}{|l|}{ PDL1 n (\%) } \\
\hline Negative & $14(82.4 \%)$ & $61(91 \%)$ & 75 & 0.378 \\
\hline Positive & $3(17.6 \%)$ & $6(9 \%)$ & 9 & \\
\hline Total & 17 & 67 & 84 & \\
\hline \multicolumn{5}{|l|}{ ALK n (\%) } \\
\hline Negative & $15(88.2 \%)$ & $66(98.5 \%)$ & 81 & 0.103 \\
\hline Positive & $2(11.8 \%)$ & $1(1.5 \%)$ & 3 & \\
\hline Total & 17 & 67 & 84 & \\
\hline \multicolumn{5}{|l|}{ CK17 n $(\%)$} \\
\hline Negative & $9(56.3 \%)$ & $36(53.7 \%)$ & 45 & 1.000 \\
\hline Positive & $7(43.7 \%)$ & $31(46.3 \%)$ & 38 & \\
\hline Total & 16 & 67 & 83 & \\
\hline \multicolumn{5}{|l|}{ CK5/6 n (\%) } \\
\hline Negative & $5(33.3 \%)$ & $30(44.8 \%)$ & 35 & 0.566 \\
\hline Positive & $10(66.7 \%)$ & $37(55.2 \%)$ & 47 & \\
\hline Total & 15 & 67 & 82 & \\
\hline \multicolumn{5}{|l|}{$\mathrm{AR} n(\%)$} \\
\hline Negative & $14(87.5 \%)$ & $55(82.1 \%)$ & 69 & 1.000 \\
\hline Positive & $2(12.5 \%)$ & $12(17.9 \%)$ & 14 & \\
\hline Total & 16 & 67 & 83 & \\
\hline \multicolumn{5}{|l|}{ Protein P63 n (\%) } \\
\hline Negative & $12(75 \%)$ & $54(80.6 \%)$ & 66 & 0.731 \\
\hline Positive & $4(25 \%)$ & $13(19.4 \%)$ & 17 & \\
\hline Total & 16 & 67 & 83 & \\
\hline \multicolumn{5}{|l|}{ Protein p53 n $(\%)$} \\
\hline Negative & $4(26.7 \%)$ & $20(30.8 \%)$ & 24 & 1.000 \\
\hline Positive & $11(73.3 \%)$ & $45(69.2 \%)$ & 56 & \\
\hline Total & 15 & 65 & 80 & \\
\hline EGFR n (\%) & & & & \\
\hline Negative & $5(31.3 \%)$ & $23(34.3 \%)$ & 28 & 1.000 \\
\hline Low to high score & $11(68.7 \%)$ & $44(65.7 \%)$ & 55 & \\
\hline Total & 16 & 67 & 83 & \\
\hline KI67 n (\%) & & & & \\
\hline Positive cells $\leq 30 \%$ & $6(46.2 \%)$ & $29(43.9 \%)$ & 35 & 1.000 \\
\hline Positive cells >30\% & $7(53.8 \%)$ & $37(56.1 \%)$ & 44 & \\
\hline Total & 13 & 66 & 79 & \\
\hline
\end{tabular}

Table II. Association of lymph nodes status with the biomarkers under study.

\begin{tabular}{|c|c|c|c|c|}
\hline \multirow[b]{2}{*}{ Biomarkers } & \multicolumn{2}{|c|}{ Lymph nodes status } & \multirow[b]{2}{*}{ Total } & \multirow[b]{2}{*}{$\begin{array}{c}\text { Fisher's } \\
\text { exact } \\
p \text {-Value }\end{array}$} \\
\hline & Negative & Positive & & \\
\hline \multicolumn{5}{|l|}{ Claudin $7 \mathrm{n}(\%)$} \\
\hline Negative & $3(7.1 \%)$ & $2(5.7 \%)$ & 5 & 1.000 \\
\hline Weak low to strong high & $39(92.9 \%)$ & $33(94.3 \%)$ & 72 & \\
\hline Total & 42 & 35 & 77 & \\
\hline \multicolumn{5}{|l|}{ PTEN n (\%) } \\
\hline Negative & $36(78.3 \%)$ & $33(86.8 \%)$ & 69 & 0.396 \\
\hline Weak positive to positive & $10(21.7 \%)$ & $5(13.2 \%)$ & 15 & \\
\hline Total & 46 & 38 & 84 & \\
\hline \multicolumn{5}{|l|}{ C-MET n (\%) } \\
\hline Negative & $19(41.3 \%)$ & $20(54.1 \%)$ & 39 & 0.275 \\
\hline Weak to strong positive & $27(58.7 \%)$ & $17(45.9 \%)$ & 44 & \\
\hline Total & 46 & 37 & 83 & \\
\hline \multicolumn{5}{|l|}{ CMYC n (\%) } \\
\hline \multicolumn{5}{|l|}{ Positive cells } \\
\hline \multicolumn{5}{|l|}{ Positive cells } \\
\hline Total & 46 & 37 & 83 & \\
\hline \multicolumn{5}{|l|}{ c-kit n (\%) } \\
\hline Negative & $24(54.5 \%)$ & $22(61.1 \%)$ & 46 & 0.651 \\
\hline Positive & $20(45.5 \%)$ & $14(38.9 \%)$ & 34 & \\
\hline Total & 44 & 36 & 80 & \\
\hline \multicolumn{5}{|l|}{ PDL1 n (\%) } \\
\hline Negative & $41(89.1 \%)$ & $34(89.5 \%)$ & 75 & 1.000 \\
\hline Positive & $5(10.9 \%)$ & $4(10.5 \%)$ & 9 & \\
\hline Total & 46 & 38 & 84 & \\
\hline \multicolumn{5}{|l|}{ ALK n (\%) } \\
\hline Negative & $45(97.8 \%)$ & $36(94.7 \%)$ & 81 & 0.587 \\
\hline Positive & $1(2.2 \%)$ & $2(5.3 \%)$ & 3 & \\
\hline Total & 46 & 38 & 84 & \\
\hline \multicolumn{5}{|l|}{ CK17 n (\%) } \\
\hline Negative & $22(48.9 \%)$ & $23(60.5 \%)$ & 45 & 0.377 \\
\hline Positive & $23(51.1 \%)$ & $15(39.5 \%)$ & 38 & \\
\hline Total & 45 & 38 & 83 & \\
\hline \multicolumn{5}{|l|}{ CK5/6 n (\%) } \\
\hline Negative & $19(42.2 \%)$ & $16(43.2 \%)$ & 35 & 1.000 \\
\hline Positive & $26(57.8 \%)$ & $21(56.8 \%)$ & 47 & \\
\hline Total & 45 & 37 & 82 & \\
\hline \multicolumn{5}{|l|}{$\mathrm{AR} n(\%)$} \\
\hline Negative & $39(86.7 \%)$ & $30(78.9 \%)$ & 69 & 0.390 \\
\hline Positive & $6(13.3 \%)$ & $8(21.1 \%)$ & 14 & \\
\hline Total & 45 & 38 & 83 & \\
\hline \multicolumn{5}{|l|}{ Protein P63 n (\%) } \\
\hline Negative & $36(80 \%)$ & $30(78.9 \%)$ & 66 & 1.000 \\
\hline Positive & $9(20 \%)$ & $8(21.1 \%)$ & 17 & \\
\hline Total & 45 & 38 & 83 & \\
\hline \multicolumn{5}{|l|}{ Protein P53 n (\%) } \\
\hline Negative & $18(41.9 \%)$ & $6(16.2 \%)$ & 24 & 0.015 \\
\hline Positive & $25(58.1 \%)$ & $31(83.8 \%)$ & 56 & \\
\hline Total & 43 & 37 & 80 & \\
\hline EGFR n (\%) & & & & \\
\hline Negative & $14(31.1 \%)$ & $14(36.8 \%)$ & 28 & 0.645 \\
\hline Low to high score & $31(68.9 \%)$ & $24(63.2 \%)$ & 55 & \\
\hline Total & 45 & 38 & 83 & \\
\hline KI67 n (\%) & & & & \\
\hline Positive Cells $\leq 30 \%$ & $18(40.9 \%)$ & $17(48.6 \%)$ & 35 & 0.649 \\
\hline Positive Cells $>30 \%$ & $26(59.1 \%)$ & $18(51.4 \%)$ & 44 & \\
\hline Total & 44 & 35 & 79 & \\
\hline
\end{tabular}


Table III. Log-rank test for equality of survival functions in 2 different groups of each biomarker.

\begin{tabular}{|c|c|c|c|c|c|c|c|c|}
\hline \multirow[t]{2}{*}{ Biomarkers } & \multicolumn{4}{|c|}{ Disease free survival (DFS) } & \multicolumn{4}{|c|}{ Overall survival (OS) } \\
\hline & Event observed & Event expected & $\operatorname{chi} 2(1)$ & $p$-Value & Event observed & Event expected & $\operatorname{chi} 2(1)$ & $p$-Value \\
\hline \multicolumn{9}{|l|}{ c-kit } \\
\hline Positive & 8 & 8.32 & 0.02 & 0.8765 & 5 & 6.06 & 0.36 & 0.5482 \\
\hline Negative & 10 & 9.68 & & & 8 & 6.94 & & \\
\hline Total & 18 & 18.00 & & & 13 & 13.00 & & \\
\hline \multicolumn{9}{|l|}{ Androgen receptor } \\
\hline Positive & 4 & 2.54 & 0.99 & 0.3205 & 3 & 2.04 & 0.53 & 0.4676 \\
\hline Negative & 17 & 18.46 & & & 13 & 13.96 & & \\
\hline Total & 21 & 21.00 & & & 16 & 16.00 & & \\
\hline \multicolumn{9}{|l|}{ Cytokeratins Ck5/6 } \\
\hline Positive & 12 & 11.81 & 0.01 & 0.9307 & 8 & 9.06 & 0.30 & 0.5853 \\
\hline Negative & 9 & 9.19 & & & 8 & 6.94 & & \\
\hline Total & 21 & 21.00 & & & 16 & 16.00 & & \\
\hline \multicolumn{9}{|l|}{ Cytokeratins Ck17 } \\
\hline Positive & 7 & 9.13 & 0.91 & 0.3390 & 5 & 6.89 & 0.94 & 0.3320 \\
\hline Negative & 14 & 11.87 & & & 11 & 9.11 & & \\
\hline Total & 21 & 21.00 & & & 16 & 16.00 & & \\
\hline \multicolumn{9}{|l|}{ Claudin 7} \\
\hline Moderate to strong high & 15 & 14.73 & 0.03 & 0.8672 & 12 & 11.47 & 0.14 & 0.7090 \\
\hline Negative to weak low & 3 & 3.27 & & & 2 & 2.53 & & \\
\hline Total & 18 & 18.00 & & & 14 & 14.00 & & \\
\hline \multicolumn{9}{|l|}{ Phosphatase - PTEN } \\
\hline Positive & 4 & 3.86 & 0.01 & 0.9380 & 4 & 2.93 & 0.49 & 0.4830 \\
\hline Negative & 17 & 17.14 & & & 12 & 13.07 & & \\
\hline Total & 21 & 21.00 & & & 16 & 16.00 & & \\
\hline \multicolumn{9}{|l|}{ Protein P63 } \\
\hline Positive & 2 & 3.76 & 1.04 & 0.3073 & 0 & 2.84 & 3.56 & 0.0592 \\
\hline Negative & 19 & 17.24 & & & 16 & 13.16 & & \\
\hline Total & 21 & 21.00 & & & 16 & 16.00 & & \\
\hline \multicolumn{9}{|l|}{ Protein p53 } \\
\hline Positive & 13 & 13.64 & 0.10 & 0.7558 & 11 & 10.16 & 0.22 & 0.6358 \\
\hline Negative & 7 & 6.36 & & & 4 & 4.84 & & \\
\hline Total & 20 & 20.00 & & & 15 & 15.00 & & \\
\hline \multicolumn{9}{|l|}{ ALK } \\
\hline Positive & 1 & 0.94 & 0.00 & 0.9491 & 1 & 0.72 & 0.12 & 0.7279 \\
\hline Negative & 20 & 20.06 & & & 15 & 15.28 & & \\
\hline Total & 21 & 21.00 & & & 16 & 16.00 & & \\
\hline \multicolumn{9}{|l|}{ PDL1 } \\
\hline Positive & 2 & 2.15 & 0.01 & 0.9117 & 3 & 1.58 & 1.46 & 0.2269 \\
\hline Negative & 19 & 18.85 & & & 13 & 14.42 & & \\
\hline Total & 21 & 21.00 & & & 16 & 16.00 & & \\
\hline \multicolumn{9}{|l|}{ C-MET } \\
\hline Positive & 13 & 10.59 & 1.15 & 0.2838 & 11 & 8.24 & 1.97 & 0.1609 \\
\hline Negative & 8 & 10.41 & & & 5 & 7.76 & & \\
\hline Total & 21 & 21.00 & & & 16 & 16.00 & & \\
\hline \multicolumn{9}{|l|}{ KI67 } \\
\hline Positive cells $>30 \%$ & 7 & 11.36 & 4.32 & 0.0378 & 4 & 8.25 & 5.54 & 0.0186 \\
\hline Positive cells $\leq 30 \%$ & 12 & 7.64 & & & 10 & 5.75 & & \\
\hline Total & 19 & 19.00 & & & 14 & 14.00 & & \\
\hline \multicolumn{9}{|l|}{ EGFR } \\
\hline Low to high score & 14 & 13.38 & 0.08 & 0.7760 & 10 & 10.46 & 0.06 & 0.8071 \\
\hline Negative & 7 & 7.62 & & & 6 & 5.54 & & \\
\hline Total & 21 & 21.00 & & & 16 & 16.00 & & \\
\hline CMYC & & & & & & & & \\
\hline Positive cells $(26-50 \%, \geq 51 \%)$ & 9 & 12.62 & 2.93 & 0.0869 & 6 & 9.39 & 3.40 & 0.0653 \\
\hline Positive cells $(<1 \%, 1-25 \%)$ & 11 & 7.38 & & & 9 & 5.61 & & \\
\hline Total & 20 & 20.00 & & & 15 & 15.00 & & \\
\hline
\end{tabular}




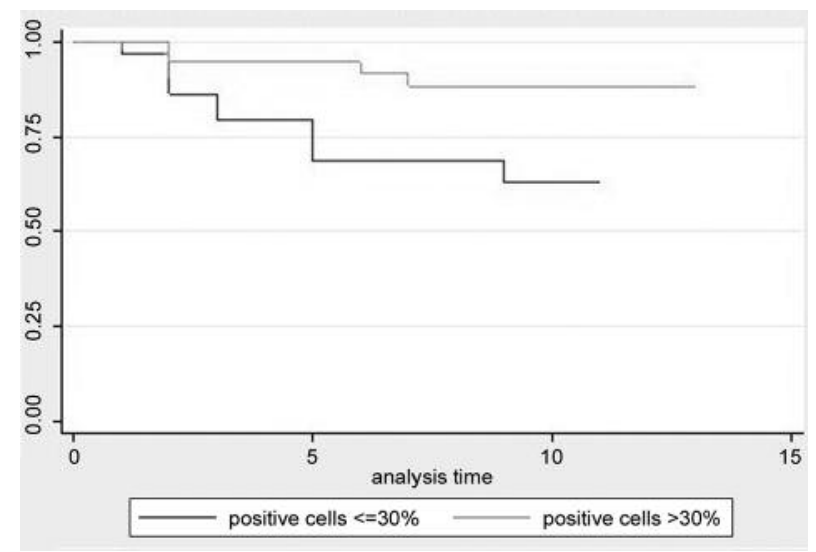

Figure 1. Kaplan-Meir overall survival estimates for cell proliferation index ki67.

have attempted to identify new biomarkers to sub-classify TNBC into different prognostic groups and to select patients who are candidates for more aggressive targeted therapy regimens.

Claudins are transmembrane proteins which have a major role on the regulation of cell adhesion, proliferation and differentiation, in controlling paracellular permeability and the maintenance of epithelial cell polarity (3-6). TNBC is often characterized by low claudin expression, especially claudin $-3,-4,-7$ (7). However, in our study, higher expression of claudin 7 was significantly correlated with higher tumor grade $(\mathrm{OR}=65.8,95 \% \mathrm{CI}=4.35-995.19, p$-value $=0.003)$. Although this observation seems to contradict the hypothesis that claudin low cells are associated with poor outcome, it is consistent with other recent studies, as the Bernardi et al. study, who did not find any association between claudin-7 and different subtypes and supported that claudin-7 expression in invasive ductal carcinoma was associated with a shorter time of recurrence, suggesting a contribution of this marker to the aggressiveness of breast cancer (8).

C-Met is a transmembrane tyrosine kinase receptor that plays a vital role in cell-cell detachment, invasiveness, tumour angiogenesis, proliferation, metastasis and survival (9). The evidence of the influence of c-Met expression on survival outcomes is inconclusive. In the present study, there was no significant correlation of c-Met expression with tumour grade, LVI and number of positive lymph nodes. However, Fisher's exact test resulted in a statistically significant relationship between AR ( $p$-value $=0.041)$ and was also significantly correlated $(p$-value $=0.002)$ with cell proliferation index Ki67 behaviour. In a recent meta-analysis by Yan et al. (10), it was shown that c-Met overexpression was associated with 1.41-fold increased risk of recurrence in the hormone positive group compared to 2.31-fold in TNBC, suggesting that c-Met could be a therapeutic target for TNBC.

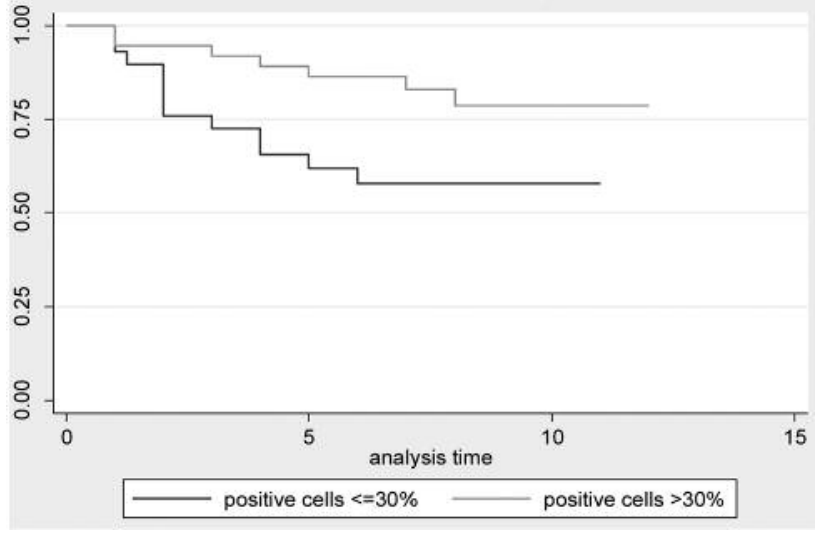

Figure 2. Kaplan-Meir disease free survival estimates for cell proliferation index ki67.

Additional high-quality data is needed in order to draw more reliable conclusions.

PTEN is a tumour suppressor $200 \mathrm{~kb}$ gene, located on chromosome 10q23 that regulates many cellular functions including cell growth, proliferation and migration. It is lost or mutated in many types of cancer including breast, prostate, and lung cancer (11). PTEN losses have been observed in up to $37-74 \%$ of TNBCs (12-14), suggesting a rationale to evaluate mTOR inhibitors in patients with TNBC as there is no alternative targeted treatment. Inanc et al. detected $44.3 \%$ PTEN loss among 99 TNBC tumors, which was also associated with shorter DFS, increased recurrence and mortality risk compared to patients without a PTEN loss. No relationship was found between PTEN loss and other clinical and pathological parameters, only that it was higher among patients with LVI (15). In the present study, no statistically significant relationship was found between PTEN loss and tumor grade, LVI, and the number of positive lymph nodes.

C-MYC is a basic helix-loop-helix zipper motif transcription factor. Its amplification is one of the most frequent aberrations in $\mathrm{BC}$ that has been detected in 1-94\% of patients in different studies and found to be associated with the basal subtype. Bouchalova et al. in a study of 187 patients with TNBC, c-MYC protein expression was found in the majority of the TNBCs (164 out of 187 patients) and was associated with worse survival (16). Horiuchi et al. investigated the biology of TNBC and identified that MYC signalling is elevated in these tumours and the expression of multiple MAX (another basic helix-loop-helix zipper protein) binding partners, which regulate MYC activity, was altered in TNBC and may therefore contribute to increased MYC pathway activity and worse patient outcome (17). In the present study, no statistically significant relationship was found between c-MYC protein expression and a role in 
regulation of cell proliferation, tumor grade, LVI, and the number of positive lymph node.

C-kit is a transmembrane tyrosine kinase receptor present on the surface of hematopoietic stem cells and also of other cells. It induces apoptosis and also increases the invasiveness of cancer cells (12). In this study the expression of c-kit appeared to be lower in patients with higher tumor grade $(\mathrm{OR}=0.14,95 \% \mathrm{CI}=0.025-0.793, p$-value $=0.026)$. Fisher's exact test resulted in a statistically significant relationship between $c$-kit $(p$-value $=0.022)$ and cytokeratins ck5/6 $(p$ value $=0.022)$. Furthermore, there was a statistically significant association between c-kit, and EGFR ( $p$ value $=0.045$ )

Similarly Tsuitsui et al. found that loss of c-kit expression was associated with lymph node metastases, and worse prognosis as it was associated with an advanced stage of breast cancer (18). Opposite results were presented by Diallo et al. who underlined that c-kit expression represents an independent negative prognostic marker in high-risk breast cancer (19). Zhu et al. evaluated the expression of c-kit protein and the mutations of the $c$-kit gene in triple negative breast cancers; $41.7 \%$ of the TNBCs positive for c-kit might benefit from tyrosine kinase inhibitors (20). Kanapathy Pillai et al. reported c-kit expression in $89 \%$ of TNBCs and this was also associated with EGFR, CK5/6 and high Ki67 proliferation index (21). The significance of c-kit expression is controversial and the rate of positive c-kit varies from 1 to $82 \%$, which is likely attributable to the different methods of determination of c-kit expression.

PD-L1, programmed cell death 1 ligand 1 , is a $40 \mathrm{kDa}$ transmembrane protein, expressed on the surface of activated cytotoxic T cells, causing inhibition of IL-2 production and $\mathrm{T}$ cell migration and proliferation (22). Few studies have investigated PD-L1 expression in BC, however the results varied regarding its expression rate and prognostic value. The present study demonstrated PD-L1 expression in $10.4 \%$ of patients while 69 out of $77(89.6 \%)$ patients did not express PD-L1 however, no statistically significant relationship was found between PD-L1 and tumor grade, LIV, and the number of the positive lymph nodes. Similarly, Beckers et al. in a study of 161 primary TNBCs, PD-L1 expression was very common in TNBC but was not an independent prognostic marker as there were differences in the outcome depending on which cellular compartment PDL1 was expressed (tumour cell membrane, cytoplasm, and stromal cellular compartment) (23). Qin et al. has shown high PD-L1 expression associated with significantly decreased survival, higher tumor grade (24).

ALK is a tyrosine receptor kinase whose pathway, has been identified by Lehmann et al. as an important signalling pathway that is common in TNBCs (25). In the present study only two women with TNBC expressed this receptor and 75 out of 77 women did not.
Cytokeratins 5/6 and 17 are important markers for the identification of the basaloid group and are correlated with poor patient outcome in TNBC (26-29). In our study $57.3 \%$ of women were found positive for CK5/6 while 35 out of 82 were negative. The expression of CK5/6 cytokeratins appeared to be lower in patients with LVI $(\mathrm{OR}=0.072$, $95 \% \mathrm{CI}=0.007-0.732, p$-value $=0.026)$. Also, a significant association was found between CK5/6 and EGFR ( $p$ value $=0.00417)$ and CK17 and Ki67 ( $p$-value $=0.041)$. These results are contradictory to many results in the literature where high expression of CK5/6 is significantly associated with worse clinicopathological features in TNBC (30)-(31). CK5/6 positive expression rates vary from 24 to $72 \%$ in the literature as, there are different scoring systems used in IHC studies for CK5/6 and no precise cutoff value exists (32).

Androgen receptor is a member of the steroid hormone receptor family, which functions as a classic ligand-activated intracellular transcription factor. AR expression in TNBC is reported lower than estrogen receptor positive breast cancers, and the prognostic value of this is still unclear. In the present study, $82.9 \%$ of women were found positive for AR while 14 out of 82 were negative. The expression of AR appeared to be much higher in patients with positive LVI $(\mathrm{OR}=13.44,95 \% \mathrm{CI}=1.28$ 141.56, $p$-value $=0.031$ ). Hu et al. who analyzed AR expression in $211 \mathrm{TNBCs}$, found that patients with AR positive tumours had an $83 \%$ increase in overall mortality compared with the ARnegative group (33). McGhan et al. found AR positive TNBCs to correlate with higher grade and LN metastases (34). Millis et $a l$. in the largest to date cohort study were 6341 breast cancers were evaluated (2,111 TNBC and 4,230 non-TNBC) showed that higher AR expression in TNBC was associated with lower ki-67 levels suggesting that androgens might have an antiproliferative effect (35). These differences in the prognostic role of AR expression are due to the variability in antibodies, scoring systems and cut-offs used to define AR positivity but also on the complexity of this pathway.

TP53 is a tumour suppressor gene that encodes a nuclear phosphoprotein. Mutation in TP53 results in loss of the usual wt-p53 tumour suppressor functions and it often exerts opposing effects. $20-35 \%$ of all breast cancers have a TP53 mutation; in TNBC TP53 mutation is present in almost all of them $(25,36)$. Previous studies have shown that $\mathrm{p} 53$ expression is higher in TNBC and that may play a role in the worse prognosis of TNBC (37). It has also been shown that breast tumours with mutant p53 were generally TNBC and were associated with decreased survival $(38,39)$. Similarly, in the present study, the expression of $\mathrm{p} 53$ was higher in patients with positive lymph nodes $(\mathrm{OR}=3.84,95 \%=\mathrm{CI}=1.22-12.07$, $p$-value $=0.021)$ suggesting worse prognosis of these patients.

Epidermal growth factor receptor (EGFR), is one of the most notable cancer molecular targets. In breast cancer, EGFR expression level or gene mutation status is increasingly being used to select patients for selective treatments. In our study, 
no statistical significant correlation was found between EGFR tumor grade, lymphovascular invasion, and the number of the positive LNs. A statistically significant association according to a Fisher's exact test was found between EGFR and c-kit $(p$-value $=0.045)$ and CK5/6 and EGFR $(p$-value $=0.004)$. The uncertainty in establishing EGFR as a prognostic and predictive factor in breast cancer is mostly due to the different methods used for the detection of EGFR dysregulation.

Ki67 immune expression is closely associated with the cell cycle and can be used as a prognostic and predictive marker $(40,41)$. In TNBC patients, high expression of Ki67 has a direct correlation with tumour size, grade and higher levels ( $>35 \%$ staining) have been linked with an increased risk of death. Ki67 levels were significantly increased in ductal TNBC compared to other histologic types $(80 \%$ in TNBC $v s$. $10-30 \%$ in other types) (42). Li et al. investigated the expression of $\mathrm{Ki} 67$ in TNBC and found that it was significantly correlated with tumour size and lymph node metastases, no correlation was observed with age and clinical stage; suggesting that Ki67 may be an indicator of poor prognosis in TNBC patients (43). Niikura et al. on the other hand showed that Ki67 was not associated with survival in the hormone receptor (HR)-negative group of 716 patients (44).

In contrast to the established predictive and prognostic value of $\mathrm{Ki} 67$ expression in patients with HR-positive tumours (45-47), there is only little evidence to support Ki67 as a predictive marker for chemotherapeutic efficacy and defining good prognosis in HR-negative breast cancers after neoadjuvant chemotherapy. Sueta et al. reported that Ki67 had no predictive value for pathologic Complete Response (pCR) in HER2 and triple-negative subtypes with neoadjuvant chemotherapy (NAC) (45). Similarly, Jones et al. also reported that $\mathrm{Ki} 67$ had no predictive value for $\mathrm{pCR}$ in triple-negative subtypes, as a greater chemotherapy sensitivity was generally observed in these tumours (48).

However, one clinical trial with 552 breast cancer patients showed that Ki67 independently improved the prediction of treatment response in a group of luminal tumours as well as triple-negative tumours post neoadjuvant chemotherapy (49). Tan et al. examined Ki67 expression as a predictor of pCR after anthracycline and/or taxane-containing neoadjuvant chemotherapy in a total 183 HR-negative patients, 61 of which were TNBC. Ki67 labelling index was a predictive marker for pathologic complete response and higher Ki67 expression was associated with HER2 status, tumor size, lymph node status, LVI and tumor grade. Also, high Ki67 expression in residual tumours was strongly correlated with poor disease-free, but not overall survival (50). How et al. has concluded that lower Ki67 has poor prognosis relevance in TNBC patients diagnosed at $\leq 50$ years-old in a study of 571 patients $(51)$.

In our study, Fisher's exact test resulted in a statistically significant relationship $(p$-value $=0.041)$ between cell proliferation index $\mathrm{Ki} 67$, which was positive in 44 out of the 79 patients, and cytokeratin 17 which was positive in 38 cases out of the 79 .

DFS and OS between groups of patients with different levels of each biomarker have been compared using log-rank test with a 5\% level of statistical significance. According to the Log-rank test, only the cell proliferation index (Ki67) has been proven to be statistically significant for the DFS $(p$-value $=0.0378)$, and for the OS $(p$-value $=0.0186)$, which means that the survival function is differentiated for the two levels of the biomarker. The significance of this biomarker has also been confirmed by the Cox regression model for DFS with backward elimination $(\mathrm{HR}=0.39,95 \% \mathrm{CI}=0.153-0.994, p$ value $=0.048$ ). We run the same Cox regression model with backward elimination for OS and it concluded that biomarker $\mathrm{Ki67}$ is an important predictor for the overall survival of patients $(\mathrm{HR}=0.277,95 \% \mathrm{CI}=0.087-0.886, p$-value $=0.03)$.

Further studies are required to assess the benefit of $\mathrm{Ki} 67$ assessment in TNBC.

P63 is a transcription factor member of the p53 gene family. Recent data suggest a complex role for p63 in breast cancer with certain studies suggesting an oncogenic role for $\Delta \mathrm{Np63}$, and others a tumor suppressor role $(52,53)$. In our study, the expression of protein p63 appeared to be lower in patients with higher tumor grade $(\mathrm{OR}=0.18,95 \% \mathrm{CI}=0.035$ $0.978, p$-value $=0.047$ ).

\section{Conclusion}

High expression of claudin-7 and low expression of c-kit and protein p63 are associated with higher tumour grade. AR and CK5/6 expression seem to be important in LVI. These findings suggest that these biomarkers may be useful as prognostic or predictive indicators, as well as possible markers for novel therapies.

\section{References}

1 Glass AG, Lacey JV, Jr., Carreon JD and Hoover RN: Breast cancer incidence, 1980-2006: Combined roles of menopausal hormone therapy, screening mammography, and estrogen receptor status. J Natl Cancer Inst 99(15): 1152-1161, 2007.

2 Quinn JE, Kennedy RD, Mullan PB, Gilmore PM, Carty M, Johnston PG and Harkin DP: Brca1 functions as a differential modulator of chemotherapy-induced apoptosis. Cancer Res 63(19): 6221-6228, 2003.

3 Lioni M, Brafford P, Andl C, Rustgi A, El-Deiry W, Herlyn M and Smalley KS: Dysregulation of claudin-7 leads to loss of e-cadherin expression and the increased invasion of esophageal squamous cell carcinoma cells. Am J Pathol 170(2): 709-721, 2007.

4 Singh AB, Sharma A and Dhawan P: Claudin family of proteins and cancer: An overview. J Oncol 2010: 541957, 2010.

5 Myal Y, Leygue E and Blanchard AA: Claudin 1 in breast tumorigenesis: Revelation of a possible novel "Claudin high" Subset of breast cancers. J Biomed Biotechnol 2010: 956897, 2010. 
6 Engelman JA, Zejnullahu K, Mitsudomi T, Song Y, Hyland C, Park JO, Lindeman N, Gale CM, Zhao X, Christensen J, Kosaka T, Holmes AJ, Rogers AM, Cappuzzo F, Mok T, Lee C, Johnson BE, Cantley LC and Janne PA: Met amplification leads to gefitinib resistance in lung cancer by activating erbb3 signaling. Science 316(5827): 1039-1043, 2007.

7 Herschkowitz JI, Simin K, Weigman VJ, Mikaelian I, Usary J, Hu Z, Rasmussen KE, Jones LP, Assefnia S, Chandrasekharan S, Backlund MG, Yin Y, Khramtsov AI, Bastein R, Quackenbush J, Glazer RI, Brown PH, Green JE, Kopelovich L, Furth PA, Palazzo JP, Olopade OI, Bernard PS, Churchill GA, Van Dyke T and Perou CM: Identification of conserved gene expression features between murine mammary carcinoma models and human breast tumors. Genome Biol 8(5): R76, 2007.

8 Bernardi MA, Logullo AF, Pasini FS, Nonogaki S, Blumke C, Soares FA and Brentani MM: Prognostic significance of cd 24 and claudin-7 immunoexpression in ductal invasive breast cancer. Oncol Rep 27(1): 28-38, 2012.

9 Sierra JR and Tsao MS: C-met as a potential therapeutic target and biomarker in cancer. Ther Adv Med Oncol 3(1 Suppl): S2135, 2011 .

10 Yan S, Jiao X, Zou H and Li K: Prognostic significance of c-met in breast cancer: A meta-analysis of 6010 cases. Diagn Pathol 10: $62,2015$.

11 Salmena L, Carracedo A and Pandolfi PP: Tenets of pten tumor suppression. Cell 133(3): 403-414, 2008.

12 Andre F, Job B, Dessen P, Tordai A, Michiels S, Liedtke C, Richon C, Yan K, Wang B, Vassal G, Delaloge S, Hortobagyi GN, Symmans WF, Lazar V and Pusztai L: Molecular characterization of breast cancer with high-resolution oligonucleotide comparative genomic hybridization array. Clin Cancer Res 15(2): 441-451, 2009

13 Martin V, Botta F, Zanellato E, Molinari F, Crippa S, Mazzucchelli L and Frattini M: Molecular characterization of egfr and egfr-downstream pathways in triple negative breast carcinomas with basal like features. Histol Histopathol 27(6): 785-792, 2012.

14 Stefansson OA, Jonasson JG, Olafsdottir K, Hilmarsdottir H, Olafsdottir G, Esteller M, Johannsson OT and Eyfjord JE: Cpg island hypermethylation of brcal and loss of prb as co-occurring events in basal/triple-negative breast cancer. Epigenetics 6(5): 638-649, 2011.

15 Inanc M, Ozkan M, Karaca H, Berk V, Bozkurt O, Duran AO, Ozaslan E, Akgun H, Tekelioglu F and Elmali F: Cytokeratin 5/6, c-met expressions, and pten loss prognostic indicators in triplenegative breast cancer. Med Oncol 31(1): 801, 2014.

16 Bouchalova K, Svoboda M, Kharaishvili G, Vrbkova J, Bouchal J, Trojanec R, Koudelakova V, Radova L, Cwiertka K, Hajduch $\mathrm{M}$ and Kolar Z: Bcl2 is an independent predictor of outcome in basal-like triple-negative breast cancers treated with adjuvant anthracycline-based chemotherapy. Tumour Biol 36(6): 4243 4252,2015

17 Horiuchi D, Kusdra L, Huskey NE, Chandriani S, Lenburg ME, Gonzalez-Angulo AM, Creasman KJ, Bazarov AV, Smyth JW, Davis SE, Yaswen P, Mills GB, Esserman LJ and Goga A: Myc pathway activation in triple-negative breast cancer is synthetic lethal with cdk inhibition. J Exp Med 209(4): 679-696, 2012.

18 Tsutsui S, Yasuda K, Suzuki K, Takeuchi H, Nishizaki T, Higashi $\mathrm{H}$ and Era S: A loss of c-kit expression is associated with an advanced stage and poor prognosis in breast cancer. $\mathrm{Br} \mathrm{J}$ Cancer 94(12): 1874-1878, 2006.
19 Diallo R, Ting E, Gluz O, Herr A, Schutt G, Geddert H, Mohrmann S, Gabbert HE, Nitz U and Poremba C: C-kit expression in high-risk breast cancer subgroup treated with highdose or conventional dose-dense chemotherapy. Verh Dtsch Ges Pathol 90: 177-185, 2006.

20 Zhu Y, Wang Y, Guan B, Rao Q, Wang J, Ma H, Zhang Z and Zhou X: C-kit and pdgfra gene mutations in triple negative breast cancer. Int J Clin Exp Pathol 7(7): 4280-4285, 2014.

21 Kanapathy Pillai SK, Tay A, Nair S and Leong CO: Triplenegative breast cancer is associated with egfr, ck5/6 and c-kit expression in malaysian women. BMC Clin Pathol 12: 18, 2012.

22 Sheppard KA, Fitz LJ, Lee JM, Benander C, George JA, Wooters J, Qiu Y, Jussif JM, Carter LL, Wood CR and Chaudhary D: Pd1 inhibits t-cell receptor induced phosphorylation of the zap70/cd3zeta signalosome and downstream signaling to pkctheta. FEBS Lett 574(1-3): 37-41, 2004.

23 Beckers RK, Selinger CI, Vilain R, Madore J, Wilmott JS, Harvey K, Holliday A, Cooper CL, Robbins E, Gillett D, Kennedy CW, Gluch L, Carmalt H, Mak C, Warrier S, Gee HE, Chan C, McLean A, Walker E, McNeil CM, Beith JM, Swarbrick A, Scolyer RA and O'Toole SA: Programmed death ligand 1 expression in triple-negative breast cancer is associated with tumour-infiltrating lymphocytes and improved outcome. Histopathology 69(1): 25-34, 2016.

24 Qin T, Zeng YD, Qin G, Xu F, Lu JB, Fang WF, Xue C, Zhan JH, Zhang XK, Zheng QF, Peng RJ, Yuan ZY, Zhang L and Wang SS: High pd-11 expression was associated with poor prognosis in 870 chinese patients with breast cancer. Oncotarget 6(32): 3397233981, 2015.

25 Lehmann BD, Bauer JA, Chen X, Sanders ME, Chakravarthy AB, Shyr Y and Pietenpol JA: Identification of human triplenegative breast cancer subtypes and preclinical models for selection of targeted therapies. J Clin Invest 121(7): 2750-2767, 2011.

26 Perou CM, Sorlie T, Eisen MB, van de Rijn M, Jeffrey SS, Rees CA, Pollack JR, Ross DT, Johnsen H, Akslen LA, Fluge O, Pergamenschikov A, Williams C, Zhu SX, Lonning PE, BorresenDale AL, Brown PO and Botstein D: Molecular portraits of human breast tumours. Nature 406(6797): 747-752, 2000.

27 Sorlie T, Perou CM, Tibshirani R, Aas T, Geisler S, Johnsen H, Hastie T, Eisen MB, van de Rijn M, Jeffrey SS, Thorsen T, Quist $\mathrm{H}$, Matese JC, Brown PO, Botstein D, Lonning PE and BorresenDale AL: Gene expression patterns of breast carcinomas distinguish tumor subclasses with clinical implications. Proc Natl Acad Sci USA 98(19): 10869-10874, 2001.

28 Sorlie T, Tibshirani R, Parker J, Hastie T, Marron JS, Nobel A, Deng S, Johnsen H, Pesich R, Geisler S, Demeter J, Perou CM, Lonning PE, Brown PO, Borresen-Dale AL and Botstein D: Repeated observation of breast tumor subtypes in independent gene expression data sets. Proc Natl Acad Sci USA 100(14): 8418-8423, 2003

29 van de Rijn M, Perou CM, Tibshirani R, Haas P, Kallioniemi O, Kononen J, Torhorst J, Sauter G, Zuber M, Kochli OR, Mross F, Dieterich H, Seitz R, Ross D, Botstein D and Brown P: Expression of cytokeratins 17 and 5 identifies a group of breast carcinomas with poor clinical outcome. Am J Pathol 161(6): 1991-1996, 2002.

30 Sutton LM, Han JS, Molberg KH, Sarode VR, Cao D, Rakheja $\mathrm{D}$, Sailors $\mathrm{J}$ and Peng Y: Intratumoral expression level of 
epidermal growth factor receptor and cytokeratin $5 / 6$ is significantly associated with nodal and distant metastases in patients with basal-like triple-negative breast carcinoma. Am J Clin Pathol 134(5): 782-787, 2010.

31 Foulkes WD, Smith IE and Reis-Filho JS: Triple-negative breast cancer. N Engl J Med 363(20): 1938-1948, 2010.

32 Ryu DW, Jung MJ, Choi WS and Lee CH: Clinical significance of morphologic characteristics in triple negative breast cancer. J Korean Surg Soc 80(5): 301-306, 2011.

$33 \mathrm{Hu}$ R, Dawood S, Holmes MD, Collins LC, Schnitt SJ, Cole K, Marotti JD, Hankinson SE, Colditz GA and Tamimi RM: Androgen receptor expression and breast cancer survival in postmenopausal women. Clin Cancer Res 17(7): 1867-1874, 2011.

34 McGhan LJ, McCullough AE, Protheroe CA, Dueck AC, Lee JJ, Nunez-Nateras R, Castle EP, Gray RJ, Wasif N, Goetz MP, Hawse JR, Henry TJ, Barrett MT, Cunliffe HE and Pockaj BA: Androgen receptor-positive triple negative breast cancer: A unique breast cancer subtype. Ann Surg Oncol 21(2): 361-367, 2014.

35 Millis SZ, Gatalica Z, Winkler J, Vranic S, Kimbrough J, Reddy S and O'Shaughnessy JA: Predictive biomarker profiling of $>6000$ breast cancer patients shows heterogeneity in tnbc, with treatment implications. Clin Breast Cancer 15(6): 473-481 e473, 2015.

36 Bertheau P, Espie M, Turpin E, Lehmann J, Plassa LF, Varna M, Janin A and de The H: Tp53 status and response to chemotherapy in breast cancer. Pathobiology 75(2): 132-139, 2008.

37 Han JS, Cao D, Molberg KH, Sarode VR, Rao R, Sutton LM and Peng Y: Hormone receptor status rather than her2 status is significantly associated with increased ki-67 and p53 expression in triple-negative breast carcinomas, and high expression of ki67 but not p53 is significantly associated with axillary nodal metastasis in triple-negative and high-grade non-triple-negative breast carcinomas. Am J Clin Pathol 135(2): 230-237, 2015.

38 Petit T, Wilt M, Velten M, Millon R, Rodier JF, Borel C, Mors R, Haegele P, Eber M and Ghnassia JP: Comparative value of tumour grade, hormonal receptors, ki-67, her- 2 and topoisomerase ii alpha status as predictive markers in breast cancer patients treated with neoadjuvant anthracycline-based chemotherapy. Eur J Cancer 40(2): 205-211, 2004.

39 Tewari M, Krishnamurthy A and Shukla HS: Predictive markers of response to neoadjuvant chemotherapy in breast cancer. Surg Oncol 17(4): 301-311, 2008.

40 de Azambuja E, Cardoso F, de Castro G Jr., Colozza M, Mano MS, Durbecq V, Sotiriou C, Larsimont D, Piccart-Gebhart MJ and Paesmans $\mathrm{M}$ : Ki-67 as prognostic marker in early breast cancer: A meta-analysis of published studies involving 12,155 patients. Br J Cancer 96(10): 1504-1513, 2007.

41 Yerushalmi R, Woods R, Ravdin PM, Hayes MM and Gelmon KA: Ki67 in breast cancer: Prognostic and predictive potential. Lancet Oncol 11(2): 174-183, 2010.

42 Munzone E, Botteri E, Sciandivasci A, Curigliano G, Nole F, Mastropasqua M, Rotmensz N, Colleoni M, Esposito A, Adamoli L, Luini A, Goldhirsch A and Viale G: Prognostic value of ki-67 labeling index in patients with node-negative, triple-negative breast cancer. Breast Cancer Res Treat 134(1): 277-282, 2012.

$43 \mathrm{Li} \mathrm{H}$, Han X, Liu Y, Liu G and Dong G: Ki67 as a predictor of poor prognosis in patients with triple-negative breast cancer. Oncol Lett 9(1): 149-152, 2015.

44 Niikura N, Masuda S, Kumaki N, Xiaoyan T, Terada M, Terao M, Iwamoto T, Oshitanai R, Morioka T, Tuda B, Okamura T, Saito Y, Suzuki Y and Tokuda Y: Prognostic significance of the ki67 scoring categories in breast cancer subgroups. Clin Breast Cancer 14(5): 323-329 e323, 2014.

45 Sueta A, Yamamoto Y, Hayashi M, Yamamoto S, Inao T, Ibusuki M, Murakami $\mathrm{K}$ and Iwase $\mathrm{H}$ : Clinical significance of pretherapeutic ki67 as a predictive parameter for response to neoadjuvant chemotherapy in breast cancer: Is it equally useful across tumor subtypes? Surgery 155(5): 927-935, 2014.

46 Viale G, Giobbie-Hurder A, Regan MM, Coates AS, Mastropasqua MG, Dell'Orto P, Maiorano E, MacGrogan G, Braye SG, Ohlschlegel C, Neven P, Orosz Z, Olszewski WP, Knox F, Thurlimann B, Price KN, Castiglione-Gertsch M, Gelber RD, Gusterson BA and Goldhirsch A: Prognostic and predictive value of centrally reviewed ki-67 labeling index in postmenopausal women with endocrine-responsive breast cancer: Results from breast international group trial 1-98 comparing adjuvant tamoxifen with letrozole. J Clin Oncol 26(34): 5569$5575,2008$.

47 Yoshioka T, Hosoda M, Yamamoto M, Taguchi K, Hatanaka KC, Takakuwa E, Hatanaka Y, Matsuno Y and Yamashita H: Prognostic significance of pathologic complete response and ki67 expression after neoadjuvant chemotherapy in breast cancer. Breast Cancer 22(2): 185-191, 2015.

48 Jones RL, Salter J, A'Hern R, Nerurkar A, Parton M, Reis-Filho JS, Smith IE and Dowsett M: Relationship between oestrogen receptor status and proliferation in predicting response and longterm outcome to neoadjuvant chemotherapy for breast cancer. Breast Cancer Res Treat 119(2): 315-323, 2010.

49 Fasching PA, Heusinger K, Haeberle L, Niklos M, Hein A, Bayer CM, Rauh C, Schulz-Wendtland R, Bani MR, Schrauder M, Kahmann L, Lux MP, Strehl JD, Hartmann A, Dimmler A, Beckmann MW and Wachter DL: Ki67, chemotherapy response, and prognosis in breast cancer patients receiving neoadjuvant treatment. BMC Cancer 11: 486, 2011.

50 Tan QX, Qin QH, Yang WP, Mo QG and Wei CY: Prognostic value of ki67 expression in hr-negative breast cancer before and after neoadjuvant chemotherapy. Int J Clin Exp Pathol 7(10): 6862-6870, 2014

51 Hao S, He ZX, Yu KD, Yang WT and Shao ZM: New insights into the prognostic value of ki-67 labeling index in patients with triple-negative breast cancer. Oncotarget 7(17): 24824-24831, 2016.

52 Memmi EM, Sanarico AG, Giacobbe A, Peschiaroli A, Frezza V, Cicalese A, Pisati F, Tosoni D, Zhou H, Tonon G, Antonov A, Melino G, Pelicci PG and Bernassola F: P63 sustains selfrenewal of mammary cancer stem cells through regulation of sonic hedgehog signaling. Proc Natl Acad Sci USA 112(11): 3499-3504, 2015

53 Buckley NE, Conlon SJ, Jirstrom K, Kay EW, Crawford NT, O'Grady A, Sheehan K, Mc Dade SS, Wang CW, McCance DJ, Johnston PG, Kennedy RD, Harkin DP and Mullan PB: The deltanp63 proteins are key allies of brca1 in the prevention of basal-like breast cancer. Cancer Res 71(5): 1933-1944, 2011.

Received December 13, 2017

Revised January 14, 2018

Accepted January 22, 2018 